\title{
Private-public partnerships: A mechanism for freight transport infrastructure delivery?
}

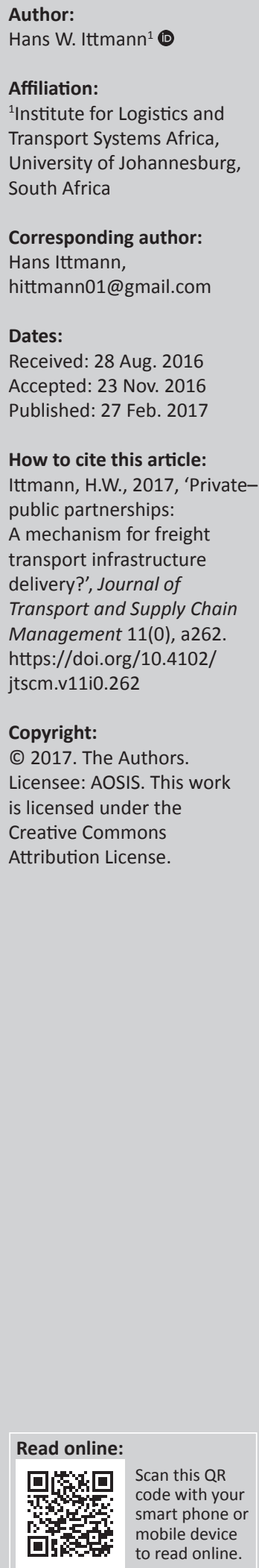

Background: Freight transport infrastructure is an indispensable requirement for economic growth, development and prosperity. Public-private partnerships (PPPs), as a mechanism to fund and construct freight transport infrastructure, have been suggested by many in private and public sectors.

Objectives: The concept of PPPs is dealt with, and the relevance of this mechanism is expanded upon. It is clear that PPPs in the rail environment present huge challenges and complexities. The objective was to determine whether PPPs are a viable mechanism to fund freight transport infrastructure in South Africa.

Method: Experiences with rail PPPs worldwide have shown that many failures occurred implementing these. The challenges and complexities of PPPs, in the freight rail environment, are highlighted together with the benefits, risks and best practices of PPPs. It is shown that suitable policies, legislation and regulations concerning PPPs are in place in South Africa.

Results: A proper framework and methodology to proceed should be in place. PPPs take time and are complex. Government involvement remains essential. Firm contractual agreements between parties are essential. Risk handling, risk sharing and the magnitude of risks should be clarified with agreement on where the risks reside. Financial viability, with value for money (VfM) and financial benefits for private sector role players are non-negotiable.

Conclusion: Appropriate legislation for implementing PPPs must be in place while two further important elements are economic circumstances and proper project execution. Taking all these factors into consideration, the freight transport sector can only benefit from successfully negotiated and implemented PPPs.

\section{Introduction and context}

The annual gross domestic product (GDP) growth rate for South Africa is estimated to be $0.2 \%$ in 2016 (Trading Economics 2016). Economic growth is of critical importance for the country. The importance of sufficient and well-maintained transport infrastructure cannot be emphasised strongly enough. Transportation infrastructure is the backbone of a modern, competitive and productive economy. Interrelated and mutually reinforcing transportation infrastructure systems facilitate the efficient movement of freight, goods and services, promote trade and commerce, connect supply chains and reduce operating costs across a diverse set of industries. Not only does infrastructure stimulate economic development and growth but ultimately also the prosperity of a country (Kessides 1993). Infrastructure development contributes to economic development through supply and demand channels, through the reduction in production costs and through contributing to the diversification of the economy. The overall effect of this is raising the quality of life of the inhabitants of a country (Jones \& Viros 2014:3, 4; Kessides 1993).

South Africa is considered a developmental state, and therefore, infrastructure is a crucial requirement for future growth. This includes transportation infrastructure such as roads, railways, ports and pipelines which in most countries the state or government should, or is expected to, provide. A country's transport infrastructure has a direct impact on logistics and supply chain management. However, the fiscus in South Africa is financially over-extended and funds are limited. This is impacting on the transport sector directly. On the main corridors, freight is mainly transported by road requiring continuous maintenance, causing accidents, pollution and so on. Provincial and local government roads are not well maintained and deteriorating. The rail infrastructure is old, costly to maintain and to upgrade, and it is very expensive to enhance and build new rail lines. 
Various calls within South Africa for the use of public-private partnership (PPP) have been made, including politicians (Makhura 2015; Nene 2015), the Department of Transport (DoT 2015:53) as well as the president of the Consulting Engineers South Africa (Thela 2015). The latter stated that South Africa is spending less than the envisaged 30\% target of GDP on infrastructure as outlined in the National Development Plan. In addition:

The use of PPPs in the financing, design, building and operation of infrastructure has emerged as the most important model employed by governments around the world to close the infrastructure gap. [But] South Africa has not yet realised the full potential of this model of infrastructure delivery. (n.p.)

The term PPPs is vague. However, in the most commonly used sense, PPPs are arrangements in which government and private sector share in a project's costs, risks, responsibilities and rewards. PPPs are thus financial instruments where public authorities use the private sector to design, build, finance, operate and maintain projects. Different combinations of these five types of project involvement can be utilised. The main reasons for private sector being involved are, firstly, private sector financial resources and, secondly, the ability of private sector to manage projects more efficiently (OECD 2013). What is provided by this efficiency is construction cost reduction, reduction in project lead time, increase in first year rate of return and improvement in annual benefit over time (Bonnafous \& Faivre d'Arcier 2013). In return, private sector seeks repayment of the debt incurred, return on the investment, limited risk and so on. Value for money (VfM) is essential for the private sector.

As a developing country, South Africa needs a growing economy which is highly dependent on an extensive transport infrastructure. Given the call and need that has been expressed for PPPs, it is critical to determine whether this is a possible and workable mechanism for transport infrastructure delivery. What does PPPs entail and what conditions are required for the successful implementation of PPPs? The emphasis of this article is twofold, namely, to get a better insight into PPPs as it relates to freight transport infrastructure, mainly road and rail, and more broadly on partnerships in intermodal freight transport. In addition, the utilisation of PPPs may be suited to enable the stated need to shift freight from road to rail (Doke 2015) that will place a bigger strain on the rail sector, specifically rail infrastructure.

This article is structured as follows: a literature review is presented initially followed by definitions of PPPs. The need for PPPs is outlined with a brief mention of benefits, risks involved and a proposed best-practice approach. A number of issues concerning PPPs in South Africa are then addressed. Policies and regulations are described, PPP challenges, examples of PPPs in the transport sector and current potential PPPs with views from various players in freight transport. The article is concluded with a summary and recommendations on how PPPs could benefit the South African economy and what is required to achieve this.

\section{Literature review}

The use of PPPs is far from novel, or even new, since it dates back a number of centuries (Corrigan et al. 2005). A toll road built by the private sector with public sector oversight and rights of way was already opened in 1793 connecting Pennsylvania farmers in the United States with the Philadelphia market and drastically reducing the travel times.

PPP in general is a well-researched topic, see for example Hodge (2004), Yescombe (2007), Hodge and Greve (2007), Pongsiri (2007), Jacobson and Choi (2008) and Koppenjan and Enserik (2009). In all cases, the topic is considered mainly from a public administrative and management point of view. De Vries and Yehoue (2013) provided a comprehensive survey of the PPP field where issues related to PPPs are addressed. Aspects that are covered include the historical context of PPPs; institutional and legal perspectives; risk allocation decision-making together with a risk model; requirements concerning organisational and institutional alignment as main factors explaining PPPs; various financial issues and aspects that need to be addressed; and different approaches that can be implemented and used. A summary article by Hall (2008) showed a growth in PPPs in Europe, but this was before the economic downturn in 2008. Hall describes three types of PPPs, namely: concession contracts, private finance initiative (contracts where the private sector company gets payments from a public sector authority) and institutional PPPs, which is a joint venture between the public and private sectors.

A comprehensive and detailed review of 27 recent rail PPPs worldwide was conducted by Dehornoy (2012). Dehornoy shows that most of these PPPs faced huge difficulties and many failed. The review focussed on PPPs in the rail sector, and passenger transport was excluded. The PPPs reviewed had to meet a number of conditions which included significant investment by concessionaires. In addition, privatisation, joint ventures, transport franchises, integrated operation concessions, rolling stock companies, public concessionaires or private projects with public regulation were also excluded from this review. Long-term trends were identified including a shift from stand-alone projects to projects that are more integrated with existing systems, integrated PPP concessions (build and operate) to strengthen PPPs, and from traffic-based (revenue is received from rail access charges or fares with no 'subsidies') towards availability-based concessions (the public authority retains commercial risk; however, it receives commercial revenue but makes payments to the concessionaire based on performance indicators). Specific features of rail PPPs established in this review were as follows:

- The majority of PPPs were technical and operational successes. From this review, it was therefore concluded that rail PPPs work from a functional perspective.

- PPPs do not create additional resources. The reason for this is that very few railways in the world are financially 
self-sustainable and can therefore hardly generate additional customer revenue. The taxpayer will ultimately have to pay for the 'pre-financing' of the rail PPP project.

- There is no evidence that PPPs are better VfM than public projects. Lifecycle costs are supposed to be less with PPPs; however, it was found that financing and transaction costs in the case of these PPPs were higher while the process of tendering and negotiating caused additional delays.

- A number of risks are specific to rail PPPs (see Table 1) and these are discussed in detail. The risks were identified as political, complex and commercial in nature. The public sector, that is, government in the broader sense, is involved in many conflicting ways in the rail sector which creates very high risks in the case of rail PPPs. PPPs as such also add additional complexity to already complex technical rail projects and this leads to rigidity.

Dehornoy (2012) analysed commercial risks in detail. The risks identified were similar in the case of both traffic-based and availability-based concessions. However, it seemed as if the commercial risks of traffic-based concessions were significantly worse than that of availability-based concessions. Most of the PPPs analysed were traffic-based concessions and most of these proved costly. Public authorities had to step in to rescue most of these PPPs. Projected traffic demands did not realise the associated high traffic demand risks and the fact that these risks are hard to mitigate. Over optimistic projected traffic forecasts, a common feature, were not achieved which lead to severe financial losses. Private partners also expected that part of the risk will be transferred to the public authority during the contract period. 'Soft' risks are mentioned as well. On a more positive note, Dehornoy found that in the case of successful PPPs, there was a shift to availability-based concessions which were more successful; that such PPP projects were more intertwined with the current rail network; and that PPPs became improvement projects rather than stand-alone projects. The outcome of all of this is clear; the risks public authorities' bear are much more than initially anticipated, whereas the private sector has almost no incentive to estimate ridership realistically.

TABLE 1: Main causes of failures of rail public-private partnerships.

\begin{tabular}{lll}
\hline Politics & Complexity & Commercial \\
\hline Lengthy decision processes & Long and complex completion & Revenue structure \\
may cause scope deviations & phase & \\
Failure to execute or & Technical intensity: proven & Demand forecast \\
interference by public & $\begin{array}{l}\text { technologies but complex } \\
\text { integration: }\end{array}$ & \\
authority & - Structures and ground & \\
& conditions & \\
& - Interaction of a variety of \\
& - systems \\
& - Safety \\
& - Functional interfaces & \\
& - Functerfaces &
\end{tabular}

'Political entrepreneur syndrome'

Public and market acceptance -

Involvement in incumbent

train-operating company

Quality of legal and

institutional framework

Source: Painvain, N., 2010, 'High speed rail projects: Large, varied and complex', in Global Infrastructure \& Project Finance, Fitch Ratings, pp. 1-19, viewed 15 September 2015, from https://www.scribd.com/document/29507989/High-Speed-Rail-Projects-Fitch
Crozet (2014) discussed how the French rail infrastructure authorities awarded a number of PPP projects between 2010 and 2012 and outlined the risks faced by the authorities. He concluded that one of the major risks the state faces is that it is often seen as the lender and operator of last resort, as it will be unacceptable to close down a service. Furthermore, decision-makers in public service behave like 'risk lovers', a major risk, which encourage optimistic behaviour from the private sector partners. To combat this risk, the public authority, in essence, needs to protect themselves against themselves!

In assessing the prospects, promise and pitfalls of PPPs in the planned US high speed rail environment, Dutzik, Schneider and Baxandall (2011) are adamant that private sector will need to play a major role. The United States needs to learn from rail PPP failures elsewhere in the world, and this prompts Dutzik et al. (2011) to present a number of key principles designed to protect public interest. The focus is strongly on the role government needs to play in PPPs. PPPs should be pursued for the right reasons and should deliver value for the taxpayer; governments should be competent and well prepared; and should retain control over key transportation-system decisions while complete transparency is essential.

In a discussion paper, to stimulate and inform the international policy debate on PPPs, to the International Transport Forum, Shaoul, Stafford and Stapleton (2012) investigated PPPs since their introduction in the UK in 1993 and what the lessons learnt were at that stage. Firstly, the clear distinction between financing and funding of PPPs is emphasised. The upfront finance for the capital expenditure comes largely from the private sector while the ultimate funding to service the costs of the project comes from either the public sector or users. Their key message is that it is actually more costly for the public sector to use the private sector as financial intermediaries. In addition, rail projects have failed to deliver the expected outputs despite receiving higher funding than was ever available under public ownership. Private sector financing adds costs, complexity, bureaucracy and risks in ways that cannot be overcome by contracts and their implementation in practice. PPPs are more costly than conventional public procurement. This higher capital cost of transport projects makes it difficult, if not impossible, for these projects to be financially viable and attractive to the private sector. In their view, this is an international phenomenon, not just a British one.

An edition of the Journal of Business Logistics (Randall 2013) contains a couple of articles that focus on PPP research in supply chain management, both from a theoretical and practical view. Sheffi (2002) addressed logistics and supply chain management issues that can arise with large-scale terrorist acts. Sheffi concluded that PPPs are not only essential but also critical to meeting the 'life or death' humanitarian objectives. 
In a South African context very little has been published about PPPs in the transport environment. Maluleka (2008) undertook an exploratory study into PPPs to look at the feasibility of introducing a transport economic regulatory authority in the country that would serve as a valid intervention mechanism for transport infrastructure to specifically protect road users. Ittmann, Viljoen, Cooper and Van Dyk (2013) stressed the need for revitalising and expanding transport infrastructure as it affects national freight logistics. Both public and private sector have a role to play in developing the required infrastructure but, although the parties have different agendas, it is imperative to work in a partnership mode. The Passenger Rail Agency of South Africa (PRASA) did not consider rail concession as an option in 2011 (Van der Walt 2011). Fombad (2014) addressed the important aspect of enhancing accountability of PPPs in South Africa, listing what the challenges are and suggesting ways to overcoming these. Looking specifically at road infrastructure, Brits (2010:39) highlighted the enormous financial burden of upgrading and maintaining road infrastructure and suggested that a 'road-user paying approach' should be acceptable if structured properly.

There is a vast source of research related to PPPs in a more general sense with a fair amount of recent research, specifically into PPPs in the rail freight transport area. Most of the latter points to failures in rail PPPs, with one author referring to the 'curse that affects PPPs in the rail sector' (Crozet 2014). Lessons learnt from these failures are captured but there are some successes where the reasons for these are highlighted. Given the lack of sufficient public sector financing in South Africa, the option of PPPs needs to be investigated. PPPs can be utilised in the construction, maintenance and operation of roads and railway lines with a further focus on intermodal freight transport facilities, to facilitate and enable the shift of freight from road to rail. It is thus necessary to get more insight into whether PPPs have the required potential to reduce the failures as reported by Dehornoy (2012) and learn from these failures to ensure that envisaged PPPs perform better. Venturing into PPPs in the transportation sector, the industry in South Africa cannot afford to repeat these failures.

\section{Public-private partnerships: A definition}

There are many definitions of PPPs that can be found in the literature but only three are presented here. The South African law defined a PPP as:

a contract between a public sector institution and a private party, in which the private party performs an institutional function and/or uses state property in terms of output specifications, assumes substantial financial, technical and operational risk in the design, financing, building and operation of a project and the private party benefits through unitary payments from government budget and/or user fees. (PPP 2015:7)

The importance of PPPs was realised by the new democratic South African government, and National Treasury established a PPP Unit (PPP 2015). The role of the PPP Unit, as originally envisaged, is to facilitate and enhance public service delivery through the creation of efficient, effective and VfM bestpractice solutions.

The United States National Council for Public-Private Partnerships (NCPPP) defined PPPs as:

a contractual arrangement between a public agency (federal, state or local) and a private sector entity. Through this agreement, the skills and assets of each sector (public and private) are shared in delivering a service or facility for the use of the general public. In addition to the sharing of resources, each party shares in the risks and rewards potential in the delivery of the service and/or facility. (NCPPP 2015:1)

De Vries and Yehoue (2013) defined PPPs as:

a public-private partnership (PPP) is a contractual arrangement with appropriate risk sharing between public and private partners for the delivery of public infrastructure or services, which is intended to create value-for-money to the taxpayer. (pp. 1-6)

Although the definitions differ and place emphasis on different aspects, there are commonalities. All three definitions indicate the need for the establishment of some contractual arrangement between public and private sector partners, contributing skills, resources and assets while both parties share in the risks as well as the rewards, or wealth, created through the partnership. All of this is intended to serve taxpayers. Efficient, effective and VfM service delivery through best-practice solutions is one of the main objectives. In the end, though, the 'value proposition', which is an inherent component of a PPP, is what will make or break a PPP. All parties, also those benefitting from the PPPs, need to get value from what is envisaged.

PPPs therefore consist of a formal and proper contract, it needs to address all risks in detail, as well as how the risks are to be shared, and finally, it needs to create VfM.

\section{The need for public-private partnerships in freight transport infrastructure and intermodal freight logistics in South Africa}

The focus of this article is on how PPPs can play a role, if any, in South Africa in the provision, maintenance, operating, etc., of freight transport infrastructure. What role and opportunities are there for PPPs in the freight intermodal transport logistics environment?

\section{Freight intermodal transport logistics}

There is consensus in the freight transport logistics industry that a significant shift of freight from road to rail is imperative in South Africa. This is underpinned by data over the last 10 years and reflected again in the Logistics Barometer (2015), the latter reporting on data from 2013. It is shown that the total freight transport activity in the country was 362 billion tonne$\mathrm{km}$; of which, $61 \%$ tonne- $\mathrm{km}$ was on road, $36 \%$ tonne- $\mathrm{km}$ was 
on rail, and the rest comprises others such as pipeline, shipping and air. It is interesting to note that the estimated split in freight tonnage for 2012 was $87.9 \%$ on road and $12.1 \%$ on rail (Havenga \& Simpson 2014:40, 41). Whichever way one looks at these facts, it is clear that road is dominant and that the big discrepancy between freight on road and rail requires freight to shift towards rail (Doke 2015). This shift will be achieved by the establishment of efficient freight transport intermodal services. In this regard, McKinnon (2012) discussed options to lowering transport intensity including modal shift as an option from the supply side. Havenga et al. (2014:6) confirmed this indicating that an effective and efficient domestic intermodal (rail-road) solution could potentially be a game changer for South Africa. The merits and potential of this are outlined in detail in Havenga, Simpson and De Bod (2012).

Freight intermodal transport utilises different modes of transport, and the strength of each mode, within such a freight transport system, ensures the most efficient freight transport movement. In addition, it is cost-effective, reduces logistics costs and shifts freight from road to rail with the associated advantages such as the reduction of externality costs (road accidents, emissions, etc.). The World Bank emphasises efficient freight transport intermodal services by stating that: 'if service delivery is poor, good physical connectivity is not enough' (Arvis et al. 2014). Intermodal freight transport services achieved through PPPs, and closer collaboration in transporting freight especially along corridors, can bring about a considerable 'shift' of freight from road to rail in South Africa.

Transnet as the main provider of rail services in the country recognises the need for PPPs or public sector participation (PSP) (Gertenbach 2014:44). Outlining the legacy of developments and challenges within the rail industry, Gertenbach (2014) discussed the rail turnaround strategy of Transnet as well as the need of collaborating with the road freight transport sector and stated:

Transnet is keen to see the private sector invest, first and foremost in their loading facilities, but also in other critical infrastructure in order to ensure that PSP initiatives are promoted and a joint investment philosophy between the private and public sector is created. (p. 44)

Transnet Freight Rail (TFR) is implementing a multi-faceted intermodal strategy which entails integration of technology solutions, revising operating models and developing such intermodal facilities. This is aimed at an integrated road and rail solution that will be cheaper than either mode used on its own. To achieve this, TFR is seeking partners to offer customers an integrated intermodal solution.

There is clearly value in establishing proper freight intermodal transport logistics solutions and should be a priority, and focus, for all role players in South Africa. This can be achieved through PPPs with many benefits. Logistics costs, mainly along corridors, will be reduced, externality costs will be reduced, less maintenance on those roads currently carrying heavy freight traffic will be required, and it will stimulate the rail sector.

\section{Freight transport infrastructure}

Ittmann (2014) outlined planned infrastructure investments in South Africa for all modes of transport. Financing is possibly the main aim and requirement for PPPs as regards freight transport infrastructure with repayments over an extended period by government or its entity. Most of the rail infrastructure in the South Africa is owned by Transnet, a state entity. Improvements or enhancements of current infrastructure could possibly be financed by PPPs to cover the upfront financing. Rail concessions for operating and maintaining rail infrastructure seem the most likely initial feasible PPP option.

The construction of new national roads under the jurisdiction of the South African National Road Agency (SANRAL), where successful PPPs have been implemented, seems ideally suited for a PPP arrangement. The challenge is with secondary roads, that is, those falling under provincial and local governments.

\section{Private-public partnerships: Benefits and risks}

PPPs have a whole range of potential benefits but there are associated risks as well that need to be considered in any such venture (World Bank 2015). A number of benefits are provided by the World Bank, and many of these have been mentioned already, as well as risks linked to PPPs. Some of the risks the World Bank highlights, include the fact that some PPP projects may be more politically or socially challenging, that contractual agreements need to be very clear and that government's responsibility continues thought the life cycle of the infrastructure. PPPs are typically long term, and thus, changes can be expected and should be anticipated. In this regard, contingencies should be provided for and be renegotiated.

Various possible PPP models exist, each offering a different level of involvement and risk as shown in Figure 1 (Urban Land Institute and Ernst \& Young 2013:33). It is interesting to note from the 10 different types of PPP agreements or model options presented, that concessions not only imply the greatest private sector involvement but also the highest risk to the private sector. This could prove to be the greatest hurdle to overcome in establishing PPPs in the rail freight environment in South Africa.

Van Herpen (2002) outlined the main advantages and disadvantages of PPPs. There are both pros and cons to PPPs. Whenever a PPP is contemplated, it is important to consider all of the different benefits, advantages, disadvantages and especially the risks involved. All those involved should realise that a PPP takes time to put in place, parties should be prepared to engage with a 'give-and-take' attitude in structuring a PPP, in order to ensure an equitable partnership. Each PPP is different and requires a different model. 


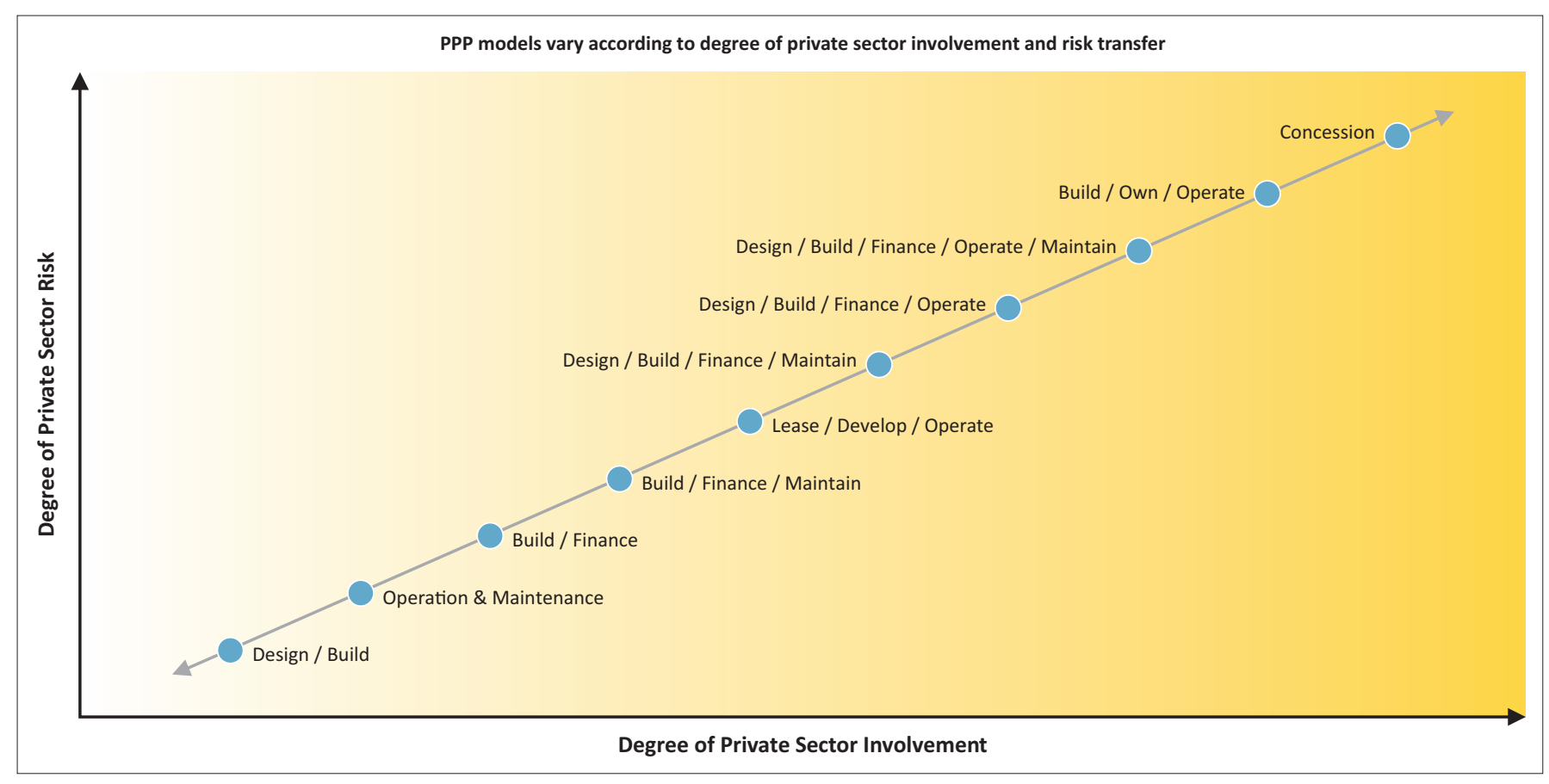

Source: Urban Land Institute and Ernst \& Young, 2013, Infrastructure 2013: Global priorities, global insights, Urban Land Institute, Washington, DC FIGURE 1: Public-private partnerships models with degree of private sector risk against private sector involvement.

\section{Best-practice public-private partnerships}

From wide experience, seven keys to 'best practices' in the development of PPPs were identified (NCPPP 2015). Not all these best practices maybe applicable in every PPP arrangement. These seven keys are as follows:

- A public sector champion: Well-informed, recognised public figures should serve as the spokespersons and advocate for the project, to minimise misperceptions about the value to the PPP.

- Proper statutory environment: A proper statutory foundation is required that is transparent with a competitive proposal process. Unsolicited proposals should be welcomed and can have a positive impact.

- Public sector's organised structure: A dedicated team from public sector for PPPs projects, should be involved throughout the duration of the project with clear roles and responsibilities.

- Detailed contract (business plan): A comprehensive contractual relationship between the parties for the execution of a project increases the probability of success.

- Clearly defined revenue stream: The revenue stream must be identifiable and sufficient to recover the investment and provide an acceptable rate of return over the term of the partnership.

- Stakeholder support: Identify all stakeholders; ensure proper, open and candid communication to negate any misconceptions; and be clear about the partnership and the value it creates.

- Pick your partner carefully: Identify the right partner. The 'best value' (not always lowest price) obtained from a partnership is critical in a long-term relationship.
Corrigan et al. (2005) outlined 10 principles to guide those involved in the development process of PPPs. The principles are aimed at ensuring the most efficient use of resources in the pursuit of mutual gains through PPPs. Both these best practices and principles entail basically what is captured in the definition of a PPP, namely, a formal contract, addressing risks and creating value. Public sector involvement and support, together with building trust with a deal that is structured fairly, can be added as critical ingredients of a PPP.

\section{Private-public partnerships in South Africa Public-private partnership policy, regulations and process}

PPPs in South Africa have been regulated since 1999 providing a clear and transparent framework for government and its private sector partners to enter into mutually beneficial commercial transactions for the public good. The legislation governing PPPs is the Public Finance Management Act and Treasury Regulation 16. A PPP Unit in Treasury is responsible for the PPP function within government (PPP 2015). The Treasury document outlines a whole range of aspects related to PPPs. Some are listed here because of its relevance:

- Characteristics of a PPP as defined by Treasury in South Africa:

- APPP is a clearly defined project, where the procuring institution carefully defines its objectives.

- The contractual relationship spans a set length of time, which may range from 5 to 30 years.

- The private party plays a key role at each stage of the project: funding, development, design, completion and implementation. 
- The funding structures of a PPP sometimes combine public and private funds.

- Payment arrangements in PPPs are based on outputs, related to the provision of services and infrastructure and services.

- PPPs are not a way of avoiding payment for capital projects. They allow the procuring institution to spread payments for large projects over the project's lifetime.

- Direct user charges, like road tolls or water fees, may also contribute to a project's revenue.

- Risks are allocated to the party most able to carry them. This means mitigating their impact and being able to absorb the consequences.

- Fixed and operational assets are adequately maintained over the project's lifetime.

- Two types of PPPs are defined in Treasury Regulation 16:

- Where the private party performs an institutional function.

- Where the private party acquires the use of state property for its own commercial purposes.

- Reasons for going the PPP route are also outlined in the policy, namely:

- PPPs leverage private party capital to fund infrastructure.

- PPPs leverage private sector skills.

- PPPs can be good for project planning.

- The private sector takes financial risk over the lifecycle of the project.

- Risks are allocated to the party best able to manage a particular risk.

- PPPs deliver budgetary certainty.

- The public sector pays only when services are delivered.

- PPPs force the public sector to focus on outputs and benefits from the start.

- The quality of service has to be maintained for the duration of the PPP.

- Specialist skills are developed and transferred to the public sector.

- PPPs encourage the injection of private sector capital.

The project life cycle of a PPP according to the PPP Unit consists of an inception phase, a feasibility study, procurement and implementation. Government is endeavouring to improve and streamline this process on a continuous basis. The three key tests for a PPP according to the PPP Unit are affordability, VfM and appropriate risk transfer.

From the brief outline of government policies and regulations regarding PPPs, everything seems to be covered. Government has created the right environment, an appropriate and comprehensive process within which PPPs can be structured to thrive and flourish.

\section{Key challenges to public-private partnerships in South Africa}

In April 2007, the views of various players from all sectors, not just the transport sector, within the PPP arena were solicited to determine the key challenges facing PPPs in South Africa, what these challenges are and how to address them (Castalia 2007). There was agreement on the following key challenges: a lack of policy direction as to the need for PPPs and an inconsistent commitment from government to PPPs; mistrust among implementing agencies of the private sector; not sufficient effort by implementing agencies towards setting up PPPs; insufficient resources within government to promote and support PPPs; policy procurement bias against PPPs; a lack of fiscal imperative to use PPPs with almost complete ignorance within municipalities towards PPPs. The report indicates that significant areas of disagreement remain. The private sector is generally sceptical towards PPPs with waning interest. There is too much emphasis on regulation. The rules and legislations are restrictive towards smaller projects. Finally, the private sector believes that the PPP Unit and the implementing agencies want to transfer too much risk onto the private sector. The implementing agencies, on the contrary, are ambivalent about PPPs, at best. Government agencies responsible for PPP policy believe all aspects related to implementing PPPs are in place. PPPs take longer, are complex to structure and do not work for all municipalities. Potential solutions to these key challenges were suggested: better communication of PPPs in the pipeline, establish teams to assist implementing agencies on specific transactions, the harmonisation of municipal PPP legislation and the streamlining of PPP regulations for certain projects. Many of the issues raised are still around and will require urgent attention if PPPs are to become a mechanism to delivering freight transport infrastructure and intermodal structures. The above illustrates clearly, misconceptions, mistrust and a lack of in-depth understanding of PPPs.

\section{Transport-related examples of public-private partnerships in South Africa}

\section{Cargo dwell time}

In a World Bank study (Kgare, Raballand \& Ittmann 2011), the main reasons why cargo dwell time in the Durban port reduced dramatically over the previous decade were identified. Utilising both quantitative and qualitative data, it was possible to show what the reasons were for this reduction. A whole range of reasons were found that caused this: major Customs reform; changes in port storage tariffs coupled with strict enforcement; massive investments in infrastructure and equipment; changing customer behaviour through proper contracting between the port operator and shipping lines, and between Customs, importers and brokers. This was achieved by PPPs between the various role players with proper contracting and the fact that those involved all benefitted financially. 


\section{Toll road concessions}

Toll road concessions are at present certainly the best examples of successful PPPs in the freight transport environment in South Africa (SANRAL 2015). The SANRAL concessions consist three routes to the private sector on a build (construct), operate (manage, maintain and upgrade) and transfer (BOT) basis. Each of these contracts comprises approximately $400 \mathrm{~km}$ of road, and at the end of the 30-year concession period, these roads will be returned to SANRAL in a pre-specified condition, without any charge. These three roads are all national roads that fall under the jurisdiction of SANRAL, an agency of the National Department of Transport (NDoT).

The concessionaires are as follows:

- Trans Africa Concessionaires (TRAC) who manage a section of the N4 travelling east between Pretoria and Maputo in Mozambique, known as the Maputo Development Corridor. The concession agreement was put in place in May 1997. The N4 is a BOT (build, operate and transfer) toll road. The concession runs over a 30-year period after which it is transferred back to South Africa and Mozambique. These countries' governments remain the legal owners of the land on which the N4 is built and will reassume responsibility for the road once the concession expires. TRAC continuously maintain, expand and rehabilitate this national road which implies that it will hand back essentially a new road in 2027 (TRACN4 2016). The tolls (revenue) collected on the route are used for various purposes. Firstly, to pay off the more R1.5 billion debt incurred by the private sector for constructing the road. Then, the costs associated with on-going road maintenance, evaluation of road conditions, operation of the toll plazas, expansion and upgrading as well as improvements of safety features need to be covered (TRACN4 2016).

The following two concessions (SANRAL 2015) are only mentioned because they are both designed along the same principles as the TRAC concession:

- N3 Toll Concessions (N3TC) who manage the N3 between Heidelberg in Gauteng and Cedara near Pietermaritzburg. In November 1999, a formal agreement between SANRAL and N3TC was signed.

- Bakwena Toll Concessionaires manage the section of the N1 north of Pretoria up to the Warmbaths interchange, and the N4 travelling west towards the Botswana border, known as the Platinum Highway. Bakwena signed a concession contract with SANRAL to construct, manage, maintain and upgrade the N1 and N4 roads in October 2000, and to date have successfully met and exceeded expectations.

'Value for money' is possibly the overriding success element of all three PPPs. As national roads, these have more traffic which adds to the success. In terms of Dehornoy (2012), these are all traffic-based concessions.

\section{Gautrain: Commuter rail transport}

The Gautrain is considered to be the largest PPP rail infrastructure project in Africa and a state-of-the-art high speed passenger rail transport system (Gautrain 2015a), that links Johannesburg, Tshwane and OR Tambo International Airport. Although this is not a freight rail project, the innovative use of a PPP approach in a rail environment is illustrated briefly. This PPP project has a number of different partners. The public partner is the Gauteng Provincial Government with other key role players through the various phases of the project being the Gauteng Department of Roads and Transport (Gautrans), the National Treasury and its PPP Unit as well as the Gautrain Management Agency (GMA). The latter being the management agency of the Gauteng province, while the Bombela Concession Company (Bombela) is the private partner (concessionaire). The latter holds the 20-year concession having designed, built and part-financed this rail system. Bombela now operates and maintains the Rapid Rail Link, manages the client interface and provides an integrated solution approach for this PPP project. The client, Gauteng Province, currently, partly subsidises this project. The case study of Gautrain (2015b) outlined the contractual arrangements for this PPP in detail.

In summary, there is a formal contractual agreement in the form of a 20-year concession while the risks are clearly identified and agreed on. The contract makes provision for a range of aspects, including a concessionaire fee, debt servicing, etc. In terms of Dehornoy (2012), this can be considered a stand-alone project with the concession being a mixture between a traffic-based and an availability-based contract although the concessionaire does carry the risk if the traffic is less than its own demand forecast. This is an example of a unique PPP model (design, build, finance [partly] and operate under concession) structured to accommodate the specific project requirements that has proven, over the last number of years, to be very successful. The punctuality and reliability of the rail service have been excellent while passenger numbers have been growing faster than expected with the resultant investment in additional rolling stock (Venter 2015).

\section{Potential public-private partnerships in South Africa}

\section{Transnet branch line concessions 2010}

Of the $20953 \mathrm{~km}$ of the total Transnet 'route' rail network within South Africa, $7278 \mathrm{~km}$ (35\%) are branch lines. Only $3928 \mathrm{~km}$ of these branch lines are currently operational, while the remaining $3350 \mathrm{~km}$ are closed (Transnet 2015). Freight volumes on branch lines are limited, and Transnet has expressed a desire to bring these branch lines under concession to private operators. Currently, there is no 'open access' policy on rail line although some private and foreign railway entities have negotiated arrangements with Transnet (2015). 
In 2010, TFR requested expressions of interest (EOI) for the issuing of concessions for branch lines (Links \& Mothibedi 2011). The intention was to give exclusive rights to third parties 'to render and operate train-operating services'. This was in line with the National Freight Logistics Strategy (NDOT 2005). TFR would retain the core assets. The following drivers were motivated for this initiative: private sector skills, expanding ownership, improved agility, unlocking market potential, unlocking investment and eliminating the subsidy drain. TFR developed, for example, what the participation model would be and the possible engagement structures. Having requested registration and EOIs from the private sector during the second half of 2010, the initiative died a silent death and nothing materialised. Over 100 private operators responded to the request. One can only speculate what the real reasons and motives were behind the lack of progress on an initiative that clearly attracted huge interest from private operators.

\section{Transnet branch line concession 2015: Douglas to Belmont}

Early in 2015, TFR re-issued a request for proposal (RFP) for the $85-\mathrm{km}$ branch line between Douglas and Belmont in the Northern Cape Province. Grain is the main commodity type that is moved along this branch line (Transnet 2015).

In the RFP, the broad objectives of this concession process are outlined. It is in line with the national transport policy as well as a specific corporate objective namely for the engagement of the private sector on the revitalisation of the branch line network wherever feasible. Specific objectives include creating and encouraging entrepreneurial business opportunities, promoting the intermodal shift of freight from road to rail, lowering the social and commercial costs of freight transportation, apportioning of risk to where it can best be managed, stimulating employment and other socioeconomic opportunities in rural areas as well as supporting government's growth strategy.

As outlined in the RFP, Transnet will retain the ownership of the branch line land and rail infrastructure (assets), while the concessionaire will be granted a long-term right of use in respect of such assets at a concession fee. Further requirements include increasing freight volumes, capital investments where applicable, and maintaining the infrastructure, while Transnet would seek to align these concession opportunities to national plans and policies for economic development. For train operations and management, the concessionaire will be obliged to use the services of Transnet Branch Line Operations and Management entity, a division within TFR. The concession model will be based on a contractual arrangement between Transnet, as the network owner, and the concessionaire, as the network custodian responsible for operations and maintenance.

\section{Sasol views on branch line concessions}

Banoo (2015) presented the views of Sasol, the international integrated energy and chemical company, on access to rail line concessions. Sasol fully supports and promotes partnering with Transnet to implement rail line concessions while it is also ready for closer interaction with Transnet on a number of critical issues. These include evaluating highversus low-density line concessions, debating different options or permutations, preparing to make difficult decisions, developing joint strategic initiatives, implementing branch line subsidised concessions and proper measuring of performance or results. A number of relevant obstacles and challenges were raised together with impacts and opportunities. Banoo also identified a number of branch lines namely the line from Sasolburg to Secunda, the line from Secunda to Hamelfontein/Ermelo and lines in the Lephalale coal field area. The sentiments expressed were in line with both government and Transnet's views on PPPs or PSPs. However, as would be expected, there are differences that would need to be resolved between the parties. Sasol mentions aspects which will require discussion such as 'subsidised concessions', requiring fixed time slots and uninterrupted pass through at major stations. The basic premise of Sasol's thinking and approach is nevertheless sound and encouraging which needs immediate further investigation. It will take time to reach agreements on issues, but with the right mind set, attitude and willingness to reach compromises, public and private sector participation can be achieved.

\section{Transnet views on private sector participation plans: 2015}

Transnet is considering PSPs (Transnet refers to PPPs as PSPs) seriously since it is 'embedded in the Transnet Shareholder (Department of Public Enterprises) Compact and Ministerial Statement of Strategic Intent' (Mackay 2015). Outlining the current context with respect to funding as well as risks within the market place, Mackay presents a number of advantages and disadvantages of having a single freight transport utility. Based on these, the conclusion is that 'public-private collaboration is critical for SA economic growth and the opportunities outweigh the challenges'. The prime driver of this PSP strategy is to obtain funding to support the Market Demand Strategy (MDS) of Transnet, but it is complemented by a number of broader objectives. This PSP strategy was approved in 2013 (with a revision in 2015), the methodology and best-practice governance are in place and a portfolio of 30 opportunities is under investigation with four projects scheduled for market offering in 2015-2016. It is envisaged that a recent partnership with the Development Bank of Southern Africa will provide project funding as well as skills and capacity to expedite delivery. The PSP portfolio includes key functional focus areas such as bulk commodities, intermodal, rail (including branch lines), ports, regional integration and non-core but MDS complementary areas.

Mackay lists the following key success factors to enable PSP transactions and expedite collaboration:

- Political vision and project sponsorship (per asset class or per project).

- Bankable and credit worthy project off-take.

- Robust methodology and approval process.

- Practical first steps - with a strategic goal in mind. 
This further indicates Transnet's keenness and confirmation on taking PSP (or PPPs) seriously. The challenge is to convert this into real action and getting PSPs in place.

\section{Passenger Rail Agency of South Africa's view on concessions in 2011}

Van der Walt (2011) expressing the views of the PRASA indicated that it was not considering concessions as an option although PRASA is willing to consider PPPs in the case of green field lines. The main reasons stated are that PPPs worldwide are fraught with severe challenges, complexities and even total failure. It was indicated that 'concessioning is not the panacea' to solving railway problems.

\section{Summary}

It is important to take note that freight traffic on rail branch lines declined over the years making it less and less economically viable, and Transnet therefore terminated the rail services within parts of this market segment. Any further investments on these lines were stopped. To remain profitable, Transnet had no alternatives. Terminating freight transport rail services to rural areas to support and encourage economic development were in direct conflict with government's national strategic objectives of a developing country. This creates major challenges for any concession opportunities including offering genuine VfM and appropriate risk sharing. The latter is a major issue especially when a company such as Sasol refers to 'subsidised concessions', indicating Sasol is not prepared to carry the risks alone. Without clear VfM and risk sharing, attempts at revitalisation of the current dormant branch lines, by involving the private sector, will be challenging and will probably not succeed.

The difference views related to PPPs between Transnet and PRASA are also interesting to note even though the views were expressed a number of years apart. Transnet is clearly more favourably inclined towards PPPs than PRASA. Having said this, there seems to be no formal PPP in place currently in the rail sector in South Africa. The environment is political, complex, and one can assume that the commercial 'value proposition' for both parties has not been satisfactorily established.

\section{Multimodal freight transport}

Two of the major freight and logistics organisations in South Africa, TFR (a state-owned organisation) and Imperial Logistics (a private sector company), signed a Memorandum of Understanding (MOU) to collaborate on getting freight off road onto rail (Greve 2013). The aim was to 'divert freight that is currently transported by road to a multimodal transport combination and amplify the use of rail in longhaul transportation'. The proposed partnership would facilitate the joint development of multimodal logistics services in support of the MDS of Transnet. The latter is aimed at reducing rail friendly freight transported on the national road network. The strengths of the respective entities would be utilised in this collaboration. Such a partnership would entail Transnet's long-haul capacity especially along the freight corridors in the country and in the case of Imperial Logistics their road freight logistics, distribution and endto-end supply chain management experience. An almost identical MOU, with similar objectives, was signed between TFR and Barloworld Logistics (Supply Chain Today 2014:41).

In both cases, the main objective is focussed on shifting longhaul freight from road to rail, where both parties are clearly keen to get something in place but implementation remains a big challenge. After almost 2 years, there is no indication that this MOU has been implemented and whether it has led to any true multimodal transport collaboration.

In the United States, where railroads are mainly privately owned, there are a number of examples of recent successful multimodal freight transport PPPs with clearly stated benefits (AAR 2014a:2, 2014b; Berman 2016; Carlson 2015; Moss Kanter 2015:39-54). The aim is not only to benefit from multimodal transport but also to ensure that freight is shifted from road to rail. In this way, 'rail friendly freight' is transported on the most appropriate mode especially over long distances.

\section{Discussion}

PPPs are not used on a regular basis as a mechanism in the South African transport sector. The exceptions are the three national road concessions that SANRAL has implemented successfully, albeit a limited number. In the rail transport sector, there is the singular successful Gautrain Rapid Rail Link dedicated mainly to rail commuters. Much can be learnt from these. All of these comply also too the 'best-practice' principles (NCPPP 2015) outlined in Section 6:

- SANRAL and the GMA are the public sector champions.

- The PPP Unit of Treasury in South Africa has developed a proper statutory environment for the establishment of PPPs.

- Dedicated teams from the public sector were established for the PPP projects with clear roles and responsibilities.

- In all cases, detailed contracts (business plans) between all parties are in place, and structured according to the needs of the project.

- There are no uncertainties with regard to revenue streams, which are clearly defined and are sufficient to recover the investment and provide VfM. Risks are dealt with to all partners' satisfaction.

- Without close stakeholder support and cooperation from all partners, it would be impossible to have such successful PPPs in place.

- Pick and identify the right partner carefully. The 'best value' (not always lowest price) obtained from a partnership is critical in a long-term relationship.

The World Bank has developed a framework for developing and building successful PPPs (World Bank 2014). This framework is shown in Figure 2 with three main elements. The political element dictates involvement of a political champion with appropriate legislation for 


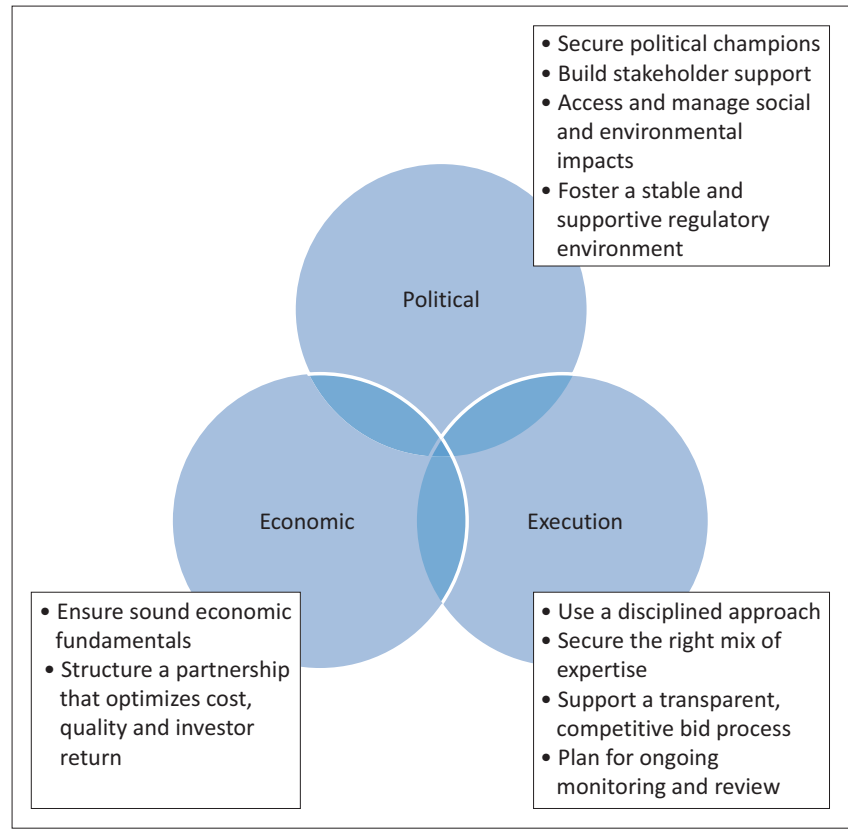

Source: World Bank, 2014, Overcoming constraints to the financing of infrastructure Success stories and lessons learned: Country, sector and project examples of overcoming constraints to the financing of infrastructure, World Bank, Washington, DC, viewed 25 September 2015, from http://www.g20australia.org/official_resources/success_stories and lessons_learned_country_sector_and_project_examples

FIGURE 2: A framework for building successful public-private partnerships.

implementing PPPs. The latter legislation is in place in South Africa. Two other important elements are economic and execution. The basic required aspects for each of these elements are presented in Figure 2.

VfM and financial benefits for the private sector role players are non-negotiable in successful PPPs. In these PPPs, public sector also realises financial and social benefits such as economic growth and development, and job creation. Risks are properly managed, agreed on and shared. Formal contracts are in place and are structured to benefit all those involved. Lessons can also be learnt from PPP failures and, in most cases, it can be traced back to no real VfM, lack of longer term life-cycle analysis, questionable assumptions and lack of risk sharing.

Why is it that there is a lack of PPPs in the South Africa freight transport area even though many politicians and private sector representatives suggest this is a useful mechanism to involve private sector in the provision of transport infrastructure? A previous head of the PPP Unit within Treasury (Dachs 2013) commenting on private sector involvement in the Strategic Infrastructure Projects initiated a few years ago indicated that the private sector will be key to building the infrastructure and developing many of the projects. Dachs stated:

What remains to be seen is the manner in which government involves them. At the moment I see a deep mistrust between public and private sectors, a distrust that arises from a public sector fear that the private sector will seek to extract profits from the needs of the country and a private sector fear that government will plan poorly and then seek to place excessive or inappropriate risks on private companies. (p. 4)
Mistrust is a serious concern which will not disappear overnight. Any PPP takes time to establish, and it is complex and requires delicate negotiations. During negotiations, various issues need to be considered but importantly also 'emotional intelligence' (Kalikow \& Monson 2015). This is critical as Kalikow and Monson explains during negotiations:

We (those involved) tend to focus on our own agendas and don't adequately take the other side's point of view into consideration, which makes us more likely to push for proposals and make arguments that don't resonate with our counterpart. Failing to read our counterparts well can damage critical relationships, waste time, and result in lost deals. (n.p.)

Is the probability of on-going successful transport sectorrelated PPPs higher at present in South Africa, given the positive views stated by various players from both the private and public sectors? Over and above key challenges for PPPs in South Africa, as stated in Section 7.2, many of which still exist, the aspect of how risk should be handled and attaining VfM from such a partnership can make or break any such initiative. The Transnet RFP from potential concessionaire for the branch line in the Northern Cape is a very positive development. If all the objectives that are listed by Transnet are considered it becomes a tall order for any private company to satisfy. Any agreement in this case will require 'give-andtake' from both parties. Transnet is prepared to consider apportioning of risk but how far are they prepared to go? One must see this in view of a large private company such as Sasol, who expressed an interest in the concept of a PPP, referring to 'subsidised concessions' and other preferences (Banoo 2015). Branch lines are typically not profitable and VfM will be difficult to achieve. To shift the responsibility of operating a branch line to a private company with no guarantees will be difficult to achieve. Nevertheless, PPPs are likely to be successful where those involved combine the capital and service requirements, the risks are primarily commercial but with some guarantees, VfM is clearly visible, the scope is such that it encourages collaboration via such partnerships and there is the presence of skilled and committed public sector management.

\section{Conclusion}

PPPs can be used as a mechanism to delivery freight transport infrastructure. In the case of road infrastructure, newly built national roads are ideally suited using the 'road-user paying approach'. In the case of freight rail, the situation is much more complex. Risks sharing and VfM is difficult to attain without some form of subsidy or financial support from the public sector. With the possibility of multimodal freight transport hubs being developed, it is an ideal opportunity for the establishment of PPPs. From international experience, these provide an ideal environment for public sector participation.

Finally, PPPs are certainly mechanisms that can be, and every endeavour should be made for the delivery of freight transport infrastructure and intermodal facilities via PPPs. Many politicians and businessmen have stated the need 
for PPPs. Despite the stated potential advantages to PPP arrangements, there can be instances where they are not appropriate. A proper framework and methodology to proceed should be in place upfront while there should be agreement on whether a project could be executed as a PPP. Government involvement is essential. PPPs take time to materialise and are complex. It is, therefore, of utmost importance that those involved should work at establishing trust relationship from the start and be committed to this. The parties should work towards a firm contractual agreement. Negotiations will require compromises from all parties involved, and there should be total transparency in the process. Risk handling, risk sharing and the magnitude of risks should be clarified in detail. Agreement on where the risks reside are critical. Decision-makers must also be sure, through life-cycle costing analysis, that projects are financially viable. Significant financial and logistical analysis must be completed before embarking on a PPP. It is only through such detailed analysis that benefits for those involved that VfM, especially for private sector partners, will be determined. Consideration must be given to whether the resources necessary for successful contract negotiation and implementation are available. PPPs are different and should be treated as such. Taking all these factors into consideration, the freight transport sector can only benefit from successfully negotiated and implemented PPPs.

\section{Acknowledgements Competing interests}

The author declares that he has no financial or personal relationships that may have inappropriately influenced him in writing this article.

\section{References}

AAR, 2014a, Public-private partnerships, Association of American Railroads, viewed 29 October 2015, from https://www.aar.org/BackgroundPapers/Public $\% 20$ Private $\% 20$ Partnerships.pdf

AAR, 2014b, Total annual spend, Association of American Railroads, viewed 29 October 2015, from https://www.aar.org/Fact\%20Sheets/Safety/2013-AAR spending-graphic-fact-sheet.pdf

Arvis, J.-F., Saslavsky, D., Ojala, L., Shepherd, B., Busch, C. \& Raj, A., 2014, Connecting to compete: Trade logistics in the global economy: The logistics performance index and its indicators, World Bank, Washington, DC.

Banoo, A., 2015, Sasol's view for access to the line concessions, presented on behalf of Mr Sello Ramoshaba, Transportsig, 04 June 2015, viewed 15 September 2015, from http://www.transportsig.com/index.php/download/search result.html?search phrase=Sasol\&catid=0\&ordering=newest \& search_mode=any\&search phrase $=$ Sa sol \& catid $=0 \&$ ordering $=$ newest $\&$ search_mode $=$ any $\&$ sea
where $\% 5 \mathrm{~B} \% 5 \mathrm{D}=$ search_name $\&$ search_where $\% 5 \mathrm{~B} \% 5 \mathrm{D}=$ search_description

Berman, J., 2016, CSX North Carolina-Based Intermodal Terminal, viewed 21 January 2016, from http://www.supplychain247.com/article/csx_north_carolina-based_ intermodal terminal

Bonnafous, A. \& Faivre d'Arcier, B., 2013, 'The conditions of efficiency of a PPP for public finances', 13th WCTR - 13th World conference on transportation research, Rio de Janeiro, Brazil, July 2013. https://halshs.archives-ouvertes.fr/ halshs-00876446/document

Brits, A., 2010, 'The financial burden of national road infrastructure and the equity thereof: A South African perspective', Journal of Transport and Supply Chain Management 4(1), 22-38. https://doi.org/10.4102/jtscm.v4i1.10

Carlson, D., 2015, Kansas City Southern increases capacity with New Wylie, Texas Intermodal Terminal, viewed 12 January 2016, from http://www.businesswire. $\mathrm{com} / \mathrm{news} / \mathrm{home} / 20150730005070 / \mathrm{en} /$ Kansas-City-Southern-IncreasesCapacity-Wylie-Texas

Castalia, 2007, Key challenges to public private partnerships in South Africa-Summary of interview findings, Report for the Support Programme for Accelerated of interview findings, Report for the Support Programme for Accelerated
Infrastructure Development (SPAID); An initiative of the Presidency of the Republic of South Africa and the Business Trust, Castalia Strategic Advisors, Republic of South Africa and the Business Trust, Castalia Strategic Advisors,
Washington DC in association with Ukhamba Advisory Services, April 2007, Washington DC in association with Ukhamba Advisory Services, April 2007,
viewed 15 September 2015, from http://castalia-advisors.com/files/12345.pdf
Corrigan, M.B., Hambene, J., Hudnut, W., III, Levitt, R.L., Stainback, J., Ward, R. et al., 2005, Ten principles for successful public/private partnerships, ULI-the Urban Land Institute, Washington, DC.

Crozet, Y., 2014, 'Extension of the high speed rail network in France: Facing the curse that affects PPPs in the rail sector', Research in Transport Economics 44, 401-409. https://doi.org/10.1016/j.retrec.2014.09.065

Dachs, W., 2013, Understanding the SIPs, National Infrastructure Programme, KPMG Advertising supplement to the Mail\&Guardian, November 29 to December 5 , 2013.

Dehornoy, J., 2012, PPPs in the rail sector $-A$ review of 27 projects, SNCF French National Railways, MPRA Paper No. 38415, Munich University Library, Munich, Germany.

De Vries, P. \& Yehoue, E.B. (eds.), 2013, The Routledge companion to public-private partnerships, Routledge, Abingdon, UK.

Doke, L., 2015, Investment still needed in transport infrastructure, Mail\&Guardian 17 July, viewed 12 Augustus 2016, from http://mg.co.za/article/2015-07-17investment-still-needed-in-transport-infrastructure

DoT, 2015, National rail policy - Green Paper August 2015, Department of Transport, Pretoria, South Africa.

Dutzik, T., Schneider, J. \& Baxandall, P., 2011, High-speed rail: Public, private or both? - Assessing the prospects, promise and pitfalls of public-private partnerships, U.S. PIRG Education Fund, Boston, MA.

Fombad, M.C., 2014, 'Enhancing accountability in public-private partnerships in South Africa', Southern Africa Business Review 18(3), 66-92.

Gautrain, 2015a, Concessionaire, viewed 28 August 2015, from http://www.gautrain. co.za/about/about-gautrain/concessionnaire/

Gautrain, 2015b, Financial model of the Gautrain rapid rail link public private partnership, GMA case study, Gautrain Management Agency, Midrand, pp. 1-11.

Gertenbach, S., 2014, 'Rail in South Africa - The legacy and way forward', in 10th Annual State of Logistics Survey for South Africa 2013 - Bold Steps Forward, CSIR, Pretoria, South Africa.

Greve, N., 2013, 'Transnet, Imperial ratify road-to-rail alliance', Engineering News, 04 October, viewed 28 August 2015, from http://www.engineeringnews.co.za/ article/transnet-imperial-ratify-road-to-rail-alliance-2013-10-04

Hall, P., 2008, Public-private partnerships (PPPS) summary paper, Public Services International Research Unit (PSIRU), The University of Greenwich, Park Row, London, UK.

Havenga, J. \& Simpson, Z., 2014, 'Critical logistics enablers - Intermodalism Freight flow on road and rail 2011-2013', in 10th Annual State of Logistics Survey for South Africa 2013 - Bold Steps Forward, CSIR, Pretoria, South Africa.

Havenga, J.H., Simpson, Z.P. \& De Bod, A., 2012, 'South Africa's domestic intermodal imperative', Research in Transportation Business \& Management 5, 38-47. https://doi.org/10.1016/j.rtbm.2012.11.006

Havenga, J.H., Simpson, Z.P., De Bod, A. \& Viljoen, N.M., 2014, 'South Africa's rising logistics costs: An uncertain future', Journal of Transport and Supply Chain logistics costs: An uncertain future', Journal of Transport and Supply
Management 8(1), Art. \#155, 1-7. https://doi.org/10.4102/jtscm.v8i1.155

Hodge, G.A., 2004, 'The risky business of public-private partnerships', Australian Journal of Public Administration 63(4), 37-49. https://doi.org/10.1111/j.14678500.2004.00400.x

Hodge, G.A. \& Greve, C., 2007, 'Public-private partnerships: An international performance review', Public Administration Review 67(3), 545-558. https://doi. org/10.1111/j.1540-6210.2007.00736.x

Ittmann, H.W., 2014, 'Critical logistics enablers - Logistics infrastructure capacity', in 10th Annual State of Logistics Survey for South Africa 2013 - Bold Steps Forward, CSIR, Pretoria, South Africa.

Ittmann, H.W., Viljoen, N.M., Cooper, A.K. \& Van Dyk, F.E., 2013, 'Bridging the gap between private industry and government in infrastructure development planning', in 32nd Annual Southern African Transport Conference (SATC 2013) CSIR International Convention Centre, Pretoria, South Africa, 08-11 July, viewed 17 March 2015, from http://researchspace.csir.co.za/dspace/handle/10204/6908

Jacobson, C. \& Choi, S.O., 2008, 'Success factors: Public works and public private partnerships', International Journal of Public Sector Management 21(6), 637-657. https://doi.org/10.1108/09513550810896514

Jones, R. \& Viros, C., 2014, Foundations for growth - Infrastructure investment in emerging markets, Llewellyn Consulting report for Trafigura, London, UK, pp. 1-64.

Kalikow, M. \& Monson, K., 2015, Why emotional intelligence matters in negotiations, viewed 12 September 2015, from http://www.supplychain247.com/article/why emotional_intelligence_matters_in_negotiations/vantage_partners

Kessides, C., 1993, The contributions of infrastructure to economic development: A review of experience and policy implications, World Bank, Washington, DC.

Kgare, T., Raballand, G. \& Ittmann, H.W., 2011, Cargo dwell time in Durban: Lessons for sub-Saharan African ports, Policy Research Working Paper 5794, World Bank, Africa Region Transport Unit, Washington, DC.

Koppenjan, J.F.M. \& Enserik, B., 2009, 'Public-private partnerships in urban infrastructure: Reconciling private sector participation and sustainability', Public Administration Review 69(2), 284-296. https://doi.org/10.1111/j.1540-6210. 2008.01974.x

Links, A. \& Mothibedi, W., 2011, Transnet Freight Rail's view on concessioning in the rail sector, Transport Forum, 05 May 2011, viewed 15 September 2015, from http://www.transportsig.com/index.php/download/cat_view/22-presentations. html?limit=5\&order=date\&dir=DESC\&start $=230$

Logistics Barometer, 2015, Logistics Barometer South Africa 2015, Stellenbosch University, viewed 16 July 2015, from http://www.sun.ac.za/logisticsbarometer 
Mackay, J., 2015, How Transnet intends to leverage Private Sector Participation to develop and improve supply chains, Transport Forum, 02 July, viewed 15 September 2015, from http://www.transportsig.com/index.php/download/ search_result.html?search_phrase $=$ McKay\&catid $=22 \&$ ordering $=$ newest $\&$ search mode=any\&search

Makhura, D., 2015, 'Gauteng aims to attract private partners into seven key infrastructure schemes', Engineering News, 02 February, viewed 25 February 2015, from http://www.engineeringnews.co.za/article/gauteng-aims-to-attractprivate-partners-into-seven-key-infrastructure-schemes-2015-02-02/rep_id:3182

Maluleka, K.J., 2008, Transport economic regulatory intervention in the transport infrastructure: A public-private partnership exploratory Study, DCom, UNISA Pretoria, January.

McKinnon, A.C., 2012, 'Green logistics, global trends and issues', presented at the World Bank Conference: Decoding Sustainable Logistics Trends, World Bank, Washington, DC, 12 June.

Moss Kanter, R., 2015, MOVE, W.W. Norton \& Company, New York.

NCPPP, 2015, Public-private partnerships defined, National Council for Public-Private Partnerships, 2015, viewed 16 September 2015, from http://www.ncppp.org/ ppp-basics/7-keys/

NDOT, 2005, National freight logistics strategy, National Department of Transport Pretoria, South Africa, viewed 15 September 2015, from http://www. portsregulator.org/images/documents/National_Freight_Logistics_Strategy.pdf

Nene, N., 2015, 2015 Budget speech, viewed 09 March 2015, from http://www. treasury.gov.za/documents/national\%20budget/2015/speech/speech.pd

OECD, 2013, Taking Stock of Public-Private Partnerships, Highlights of the International Transport Forum 2013 Funding Transport: Session Summaries, 22 May 2013, OECD Publishing. http://dx.doi.org/10.1787/itf highlights-2013-en

Painvain, N., 2010, 'High speed rail projects: Large, varied and complex', in Global Infrastructure \& Project Finance, Fitch Ratings, pp. 1-19, viewed 15 September 2015, from https://www.scribd.com/document/29507989/High-Speed-Rail-Projects-Fitch

Pongsiri, N., 2007, 'Regulation and public-private partnerships', The International Journal of Public Sector Management 15(6), 487-495. https://doi. org/10.1108/09513550210439634

PPP, 2015, Introducing public private partnerships in South Africa, viewed 13 July 2015, from http://www.ppp.gov.za/Documents/Final\%20Intro\%20to\%20PPP\% 20 in $\% 20$ SA $\% 2021 \% 2009 \% 2007$.pdf

Randall, W.S., 2013, 'Public-private partnerships in supply chain management', Journal of Business Logistics 34(4), 319. https://doi.org/10.1111/jbl.12029

SANRAL, 2015, Current concession contracts, viewed 28 August 2015, from http:// www.nra.co.za/live/content.php?Session_ID=9dbedeb4d1d1376c007db9461328 9f6a\&Category ID $=62$

Shaoul, J., Stafford, A. \& Stapleton, P., 2012, 'The fantasy world of private finance fo transport via public private partnerships', Discussion Paper No. 2012-6, prepared for the Roundtable on: Public Private Partnerships for Funding Transport Infrastructure: Sources of Funding, Managing Risk and Optimism Bias, Mancheste Business School, University of Manchester, United Kingdom, 27-28 September.
Sheffi, Y., 2002, Supply chain management under the threat of international terrorism, Massachusetts Institute of Technology Engineering Systems Division, Working Paper Series, ESD-WP-2003-01.27-ESD Internal Symposium, 29-30 May, viewed 12 March 2015, from http://esd-stage.mit.edu/WPS/internal-symposium/esd12 March 2015,

Supply Chain Today, 2014, 'True collaboration', Supply Chain Today, March 2014, p. 41.

Thela, A., 2015, 'Engineers urge use of PPPs to reinvigorate ailing infrastructure rollout', Engineering News, 11 February, viewed 25 February 2015, from http://www. engineeringnews.co.za/article/engineers-urge-use-of-ppps-to-reinvigorateailing-infrastructure-roll-out-2015-02-11/rep_id:3182

TRACN4, 2016, Company profile, viewed 24 August 2016, from http://www.tracn4. co.za/company-profile.html

Trading Economics, 2016, South Africa GDP growth rate, viewed 12 August 2016, from http://www.tradingeconomics.com/south-africa/gdp-growth/forecast

Transnet, 2015, Branch line concessions - Request for proposals: Volume 1 Instructions to respondents and bidders, viewed 28 September 2015, from http:// www.transnetfreightrail-tfr.net/Supplier/Documents/D-B\%20RFP\%20Vol\%201 Instruction\%20to\%20Bidders_Final_Feb_2015.pdf

Urban Land Institute and Ernst \& Young, 2013, Infrastructure 2013: Global priorities, global insights, Urban Land Institute, Washington, DC.

Van der Walt, D., 2011, Views on rail passenger concessioning, Transport Forum 05 May 2015, viewed 15 September 2015, from http://www.transportsig.com/ index.php/download/cat_view/22-presentations.html?limit=5\&order=date\&dir= DESC\&start $=230$

Van Herpen, G.W.E.B., 2002, Public private partnerships, advantages and disadvantages examined, Association of European Transport, viewed 23 January 2015, from file:///C:/Users/hittmann/Downloads/public-private-partnershipsthe-advantages-and-disadvantages-examined $\% 20(1)$.pdf

Venter, I., 2015, 'Gautrain to buy more rolling stock, reconsiders funding model', Engineering News, 06 July, viewed 02 January 2015, from http://www. engineeringnews.co.za/article/gautrain-to-buy-new-rolling-stock-reconsidersfunding-model-2015-07-06

World Bank, 2014, Overcoming constraints to the financing of infrastructure - Success stories and lessons learned: Country, sector and project examples of overcoming constraints to the financing of infrastructure, World Bank, Washington, DC, viewed 25 September 2015, from http://www.g20australia.org/official resources/success_stories_and_lessons_learned_country_sector_and_project examples

World Bank, 2015, Government objectives: Benefits and risks of PPPs, Public-Private Partnership in Infrastructure Resource Center, World Bank, Washington, DC, viewed 28 August 2015 from http://ppp.worldbank.org/public-privatepartnership/overview/ppp-objectives

Yescombe, E.R., 2007, Public-private partnerships: Principles of policy and finance, Butterworth-Heinemann, Boston, MA. 